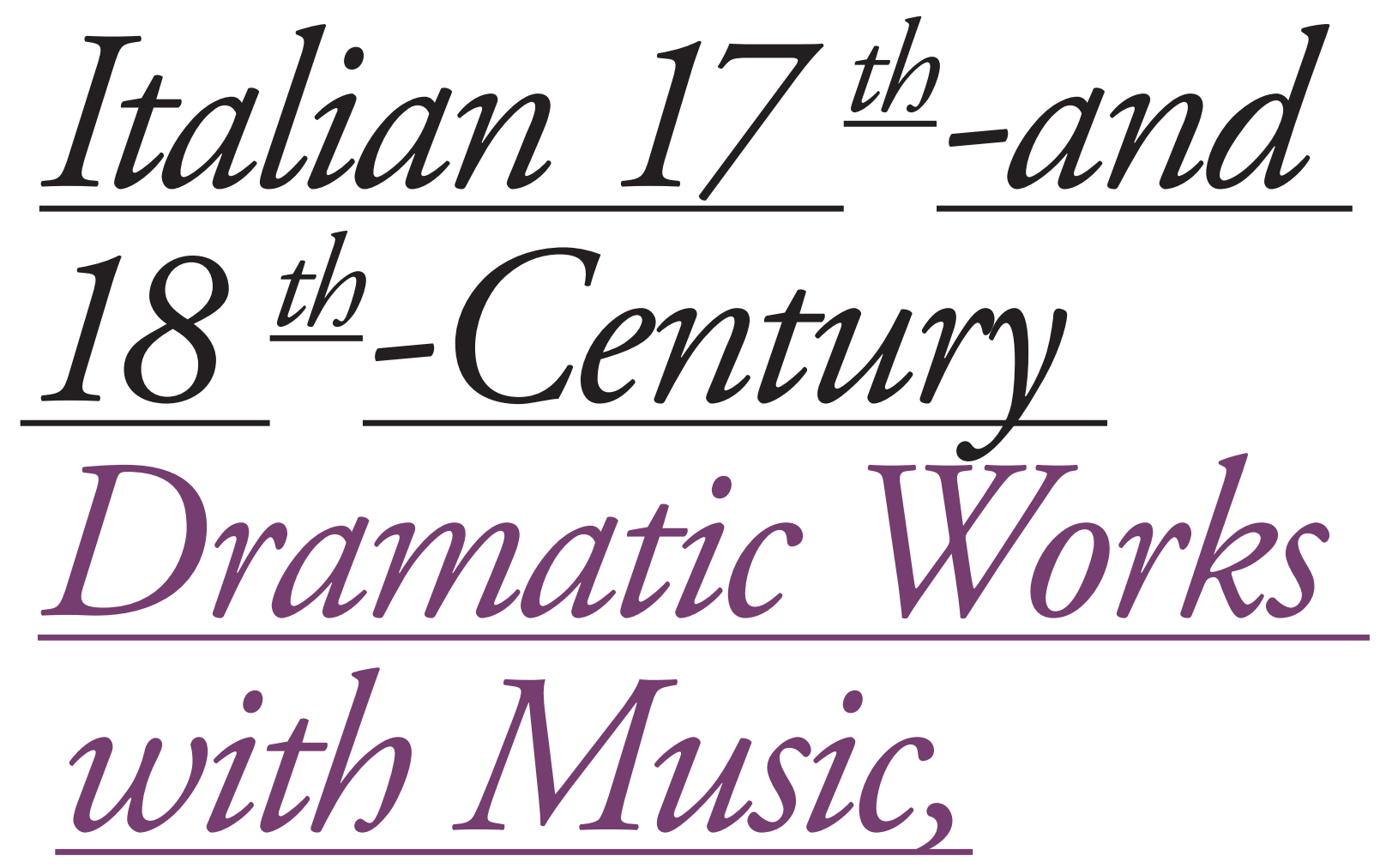

Written for the Clothing and

Profession Ceremonies, with Special Reference to Compositions Based on the Book of Judith*

\title{
ANNA RYSZKA-KOMARNICKA
}

Institute of Musicology, University of Warsaw

Email: a.ryszka-komarnicka@uw.edu.pl

*Materials for this article were collected as part of the project 'Ksiega Judyty w oratoriach wtoskich epoki baroku (1621-ok. 1750)' ['The Book of Judith in Italian Baroque Oratorios, 1621-c. 1750'], financed by the National Science Centre Poland on the basis of decision no. DEC-2011/01/B/HS2/04723.

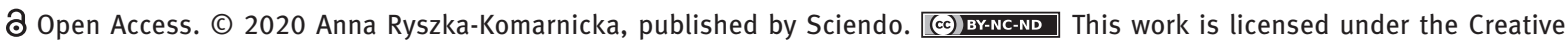
Commons Attribution-NonCommercial-NoDerivatives 3.0 License. 
sciendo

Musicology Today • Vol. $17 \cdot 2020$

DOI: 10.2478/muso-2020-0004

\section{$\underline{A B S T R A C T}$}

Late $16^{\text {th }}$ - and early $17^{\text {th }}$-century Italian theatrical works (with or without music) based on the Book of Judith are perceived as associated with women, who acted as their performers (in female monasteries), dedicatees, or patrons. This paper considers the reasons for the loosening of such ties in the Baroque genres of dialogue and oratorio, which evolved in the circles of religious and lay congregations, in which women were either marginalised or altogether excluded. The link between women and the oratorio genre was thus maintained only in the case of the so-called palace oratorios. Oratorios did not gain a solid footing in the music life of female religious orders, either. Their presence mainly made itself felt in the space suspended between the monastic and secular worlds, namely, in the context of the ceremonies of clothing and profession, which were celebrated with performances of cantatas, dialogues, or oratorios. A survey of such repertoire from the $17^{\text {th }}$ and $18^{\text {th }}$ centuries has revealed an astonishing wealth of subjects and approaches: allegorical works, saints' lives, Old Testament stories praising parents who offered their children up to God, happy weddings, or the deeds of extraordinary women. The Book of Judith occupies an important place among the latter subjects, which emphasised the fides and fortitudo of those entering monastic life. Existing works (such as Metastasio's Betulia) were also sometimes used. Some texts were written specially for such occasions, and they demonstrate individual qualities. Metastasio's solemn and exalted model was followed even in such smallscale pieces as the Florentine componimento sacro Giuditta of 1750. The rappresentazione La Giuditte (1621) depicts the strength of faith not only of Judith herself, but also (contrary to the Biblical account) - of the Bethulian society as an allegory of Bologna and its inhabitants. Comic elements were smuggled into the Paduan oratorio Giuditta (1735). To sum up, dramatic works with music based on the Book of Judith, written for the ceremonies of women entering the monastery, which have hitherto remained marginal to academic research, represent a promising field for further studies.

Key words: Book of Judith, Italian oratorio, female monasteries, clothing ceremony, profession ceremony

SEVERAL COMMENTS ON THE BOOKOF UUDITH, WOMEN, AND ORATORIOS

In the Baroque, the Book of Judith was a highly popular source of religious motifs taken up in the fine arts, literature, and music. In Italian repertoires alone, I have been able to identify 71 different dramatic works on these themes, written in lingua volgare or latina, and meant for performance with musical settings ${ }^{1}$. These

1 Cf. A. Ryszka-Komarnicka, Księga Judyty w oratoriach włoskich epoki baroku [The Book of Judith in Italian Baroque Oratorios], Appendix: 'Katalog włoskich dzieł dramatycznych opartych na Księdze Judyty (1621-1764), przeznaczonych do opracowania muzycznego'['Catalogue of Italian Dramatic Works Based on
Italian 17th-and 18th-Century Dramatic Works with Music, Written for the Clothing and Profession Ceremonies, with Special Reference to Compositions Based on the Book of Judith

include: nine rappresentazioni sacre and sixty-two nonstage compositions (oratorios, in some cases dialogues or cantatas), written in the years 1621-1764. Some of them were performed and disseminated in print many times (altogether I have found nearly 140 such recorded instances). My list omits the numerous settings of Metastasio's oratorio La Betulia liberata, except for its first Viennese premiere with music by Georg Reutter Jr $(1734)^{2}$. This event, on the one hand, summed up some of the trends in the manner the Book of Judith had been used in Italian Baroque oratorios. On the other, it opened a new chapter in the history of such adaptations, which lasted until the late $18^{\text {th}} /$ early $19^{\text {th }}$ centuries, and musically already belonged to a different era. The popularity of Betulia led to a reduction in the number of new libretti on this subject written in the Italian Peninsula. Only a few of them appeared in 1734-1764, and this was followed by nearly 20 years in which Italian authors abandoned the theme altogether.

Relatively few (only c. 20\%) of these events were related to the intention of honouring women or satisfying their artistic interests ${ }^{3}$. Hitherto research into the ways this topic was exploited in the Italian art of the late $16^{\text {th }}$ and early $17^{\text {th }}$ centuries suggests there should be more such cases. It has been indicated by researchers that the theatrical repertoire based on the Book of Judith (including texts set to music in their entirety, such as the Florentine $L a$ Juditta by librettist Andrea Salvadori and composer Marco da Gagliano, 1626) was particularly closely associated with the culture of female monasteries and the patronage of rich and powerful women, some of whom even held the helm of the state ${ }^{4}$. Such repertoire was a convenient

the Book of Judith (1621-1764), Meant for Performance with Musical Settings'], Warszawa, Instytut Muzykologii UW, 2017, pp. 451-529 (the list in the Appendix also includes several pieces by non-Italian authors who had very close links to Italy).

2 For a list of musical settings and performances of Betulia, cf. M. Valente, 'Introduzione', in P. Anfossi, Betulia liberata, G. Pelliccia (ed.), Roma, MOS edizioni, 2008, pp. XI-XXIX.

3 For a list of such works, cf. Ryszka-Komarnicka, Księga Judyty..., pp. 440-442.

4 E. Weaver, Convent Theatre in Early Modern Italy: Spiritual Fun and Learning for Women, Cambridge, Cambridge University Press, 2002 (especially at pp. 141-148); K. Harness, Echoes of Women's Voices: Music, Arts and Female Patronage in Early Modern Florence, Chicago-London, The University of Chicago Press, 2006; K. Harness, 'Judith, Music, and Female Patrons in Early Modern Italy', in K.R. Brine, E. Ciletti and H. Lähnemann (eds), The Sword of Judith. Judith Studies Across the Disciplines, Cambridge, Open Book Publishers, 2010, pp. 371-383; P. Cosentino, Le virtù 


\section{sciendo}

medium for their self-expression, self-promotion, or even for the legitimization of their social position. Numerous 'galleries' of famous women as well as writings representing the then querelle de fermmes debate have been studied. In those texts, both the adversaries and the (male and female) apologists of the fair sex represented Judith either as a type of a beautiful and crafty woman dangerous to men, or as a paragon of the noblest of virtues ${ }^{5}$. Research into the links between the Judith theme and women in the Baroque Italy has been complemented by studies of paintings which they either created themselves ${ }^{6}$ or commissioned. To sum up, the Judith theme has been described as symbolic of the discourse about gender and power in early modern Europe ${ }^{7}$.

Such a proto-feminist context for the artistic treatments of the Book of Judith is, however, only one of its many possible interpretations in the Christian tradition ${ }^{8}$, and one alien to the Old Testament tradition at that. As Deborah Levine Gera observed, "Judith has much to do and say in our book, but neither her voice nor that of her author is a female voice." "As a prefiguration of Mary and a figura ecclesiae, Judith played a major role in the Catholic Church's propagandist programme in the age of the Counter-Reformation and the Turkish wars. This role was reinforced by the official confirmation of the canonical status of this book of the Bible in $1545^{10}$. The Book of Judith was particularly favoured by the Jesuits; one of the then most influential dramatic texts based on this theme, Stefano Tuccio's Juditha $(1564)^{11}$, originated in their circles.

di Giuditta. II tema biblico della 'mulier fortis' nella letteratura del '500 e del '600, Roma, Aracne Editrice, 2012, passim.

5 Cosentino, Le virtù..., especially chapter I: La vedova di Betulia nella trattatistica filogina del XVI secolo.

6 M.D. Garrard, Artemisia Gentileschi. An Image of the Female Hero in Italian Baroque Art, Princeton, New Jersey, Princeton University Press, 1989.

7 Cf. M. Stocker, Judith. Sexual Warrior. Women and Power in Western Culture, New Haven-London, 1998.

8 E. Ciletti and H. Lähnemann, 'Judith in the Christian Tradition', in Brine, Ciletti, Lähnemann (eds), The Sword of Judith, pp. 4165.

9 D. Levine Gera, 'Introduction', in D. Levine Gera (intr., ed. and comm.), Judith, Berlin-Boston, De Gruyter, 2014, p. 109.

10 L. Borsetto, 'Trionfante e vittoriosa. Icone di Giuditta nell'epica del Seicento', in L. Borsetto (ed.), Giuditta e alter eroine bibliche tra Rinascimento e Barocco. Orizzonti di senso e di genere, variazioni, riscritture, Padova, Padova University Press, p. 76.

11 Borsetto, 'Trionfantee vittoriosa', p. 77.
Italian 17th-and 18th-Century Dramatic Works with Music, Written for the Clothing and Profession Ceremonies, with Special Reference to Compositions Based on the Book of Judith

Some of the plays about Judith were dedicated to men (for instance, Giovanfrancesco Alberti's tragedy Oloferne, whose edition of 1594 was dedicated to Cardinal Michele Bonnelli, great nephew of Pius V). Judith could even be an allegory of the pope, who identified himself with the Chiesa militante $^{12}$. In Renaissance and Baroque homiletic texts written in France $^{13}$, and (as I discovered during my research) also in Italy, Judith was held up as a model to be emulated by both men and women, both lay persons and ecclesiastics. There is no reason why oratorios, as a form of 'sermons with music', should not have followed the same tendency.

Taking into account the key context in which oratorios were performed in $17^{\text {th }}$ - and $18^{\text {th }}$-century Italy, the rather modest presence of female voices in this repertoire comes as no surprise. As a musical-literary genre, the oratorio evolved slowly and gradually in the $1^{\text {st }}$ half of the $17^{\text {th }}$ century as part of the so-called esercizi spirituali, that is, meetings which combined sermons and prayers with artistic performances. They were held by the Oratorian Fathers in Rome, as well as various fraternities, companies, and lay societies, frequently operating under the strict supervision of male religious orders (such as Jesuits, Theatines, and others). The objective of these meetings was to deepen religious life through prayer, charitable and educational work. Some of these congregations excluded women as members; one example is the Arciconfraternita di Santa Maria della Morte in Bologna ${ }^{14}$, famed for excellent oratorio performances. In others, the function of women was purely nominal, since they could not hold any posts in their structures, and their participation in the esercizi spirituali was limited to some selected days of the year ${ }^{15}$. The Oratorian Fathers similarly restricted women's presence to special occasions such as Marian feasts and those dedicated to St Cecilia ${ }^{16}$. It is therefore only natural that the repertoire promoted by these institutions was

12 E. Ciletti, 'Judith Imagery as Catholic Orthodoxy in CounterReformation Italy', in Brine, Ciletti, Lähnemann (eds), The Sword of Judith, pp. 345-368.

13 K.M. Llewellyn, Representing Judith in Early Modern French Literature, London, Routledge, 2016, p. 116.

$14 \mathrm{~J}$. Riepe, Die Arciconfraternita di S. Maria della Morte in Bologna. Beiträge zur Geschichte des italienischen Oratoriums im 17. und 18. Jahrhundert, Paderborn-München, Ferdinand Schöningh,1998, p. 19.

15 Ch.F. Black, Italian Confraternities in the Sixteenth Century, Cambridge, Cambridge University Press, 1989, pp. 34-38.

16 H.E. Smither, A History of the Oratorio, Vol. 3: The Oratorio in the Classical Era, Oxford, Clarendon Press, 1987, p. 14. 
not related to women in any fundamental respect, either with regard to the choice of topics or their adaptations for the needs of a given oratorio. Though there were some exclusively female congregations, the printed $17^{\text {th }}$ - and $18^{\text {th }}$-century libretti prove that their role in promoting the oratorio performances which accompanied these religious meetings was modest at best. Among the repertoire under study, based on the Book of Judith, I have been able to identify only one libretto print that may have been related to women's activity. Its full title, as found on the title page, emphasises the presence of Laura d'Este, head of the Congregation of the Annunciation to the Blessed Virgin Mary, at the performance of the oratorio La Giuditta in Padua's Church of San Leonardo $(1713)^{17}$. It is, however, also possible that this noble lady was merely an honorary guest at a meeting otherwise meant for a male audience. Such invitations were quite frequent; they aimed to add prestige to the event or resulted from various obligations towards the high and mighty families ${ }^{18}$.

On equal terms and with no special invitations or permissions, women could attend oratorio performances held as part of secular (courtly or aristocratic) patronage. Some patrons chose private chapels as venues for the presentation of such works, while others preferred to have them staged in palaces. The latter trend, referred to by researchers as the 'palace oratorio'19, was most likely initiated by a woman, Queen Christina of Sweden, who, having settled in Rome (1655/56), eagerly attended Lenten oratorio spectacles in that city, and decided that she wanted to have similar pious entertainment staged

17 La Giuditta. Oratorio da rapresentarsi nella Chiesa di S. Leonardo in Padova l'anno 1713 essendo presidente la nobil signora Laura d'Este della Congregazione della Santissima Annonziata, Padova, [1713].

18 These doubts are confirmed by the comparison of the said title page (cf. footn. 17) with another libretto print from Padua, in which the performance of an oratorio is unequivocally related to the presence of members of a women's congregation (underlining by A.R.-K.): La sposa de cantici piamente considerata nella diletta consorte di Gesù appassionato S. Catarina da Siena domenicana. Dialogo per musica da cantarsi nella chiesa di Sant'Agostino de PP. Predicatori. Consacrato alle nobilissime dame della congregazione di detta santa, essendo presidente la nobil signora Elena Maria Descalzi, Padova, 1706.

19 A. Morelli, '"Un bell'oratorio all'uso di Roma": Patronage and Secular Context of the Oratorio in Baroque Rome', in C. Reardon and S. Parisi (eds), Music Observed: Studies in Memory of William C. Holmes, Michigan, Warren, 2004, p. 334. at her own residence ${ }^{20}$. Outside the Eternal City, women singers were favourably received as performers of the female roles in the palace oratorios ${ }^{21}$. It is therefore from the courtly and aristocratic circles that we have the largest number of works based on the Book of Judith and related in various ways (in their origins or because of later performances following the premiere) to women, who acted as their patrons, dedicatees, or simply as high-born guests eager to attend such spectacles.

There are, however, several compositions based on the Book of Judith in whose case women's involvement in their performances was different from the roles listed above. They were pieces sung or played exclusively by women, or commemorating the occasion of aristocratic ladies entering a nunnery or convent. Apart from oratorios performed by the Cori of the Venetian Ospedali (which have been the subject of numerous publication ${ }^{22}$ ), the remaining works are interrelated by the context of women entering cloistered life. It is this part of the Judith repertoire that I will now discuss in more detail.

\section{ORATORIOS IN FEMALE CLOISTERS}

I have already mentioned the living tradition of staging theatrical plays at female monastic establishments in the $16^{\text {th }}$ and the early $17^{\text {th }}$ centuries. Music played a major role in those spectacles ${ }^{23}$. The oratorio might seem a natural successor to this practice since the genre was, on the one hand, an heir to the early, musically performed rappresentazioni spirituali (featuring stile recitativo), and on the other, as a non-stage work, it provided a morally safe type of entertainment with religious content, free of the powerful visual impact of the theatre, which many ecclesiastics considered

20 Morelli, Music Observed, pp. 335-337.

21 J. Riepe, 'Jenseits des Betsaals. Oratorienaufführungen im Profanen Kontext im Italien des 17. und 18. Jahrhunderts', Händel Jahrbuch, no. 55, 2009, pp. 59-60.

22 For more on this subject, cf. D. Arnold, 'Orphans and Ladies: the Venetian Conservatoires (1680-1790)', in Proceedings of the Royal Musical Association 1962-1963, pp. 31-47; J.L. Baldauf-Berdes, Women Musicians of Venice. Musical Foundations, 1525-1855, Oxford, Clarendon Press, 2004; H. Geyer, Das Venezianische Oratorium 1750-1820: Einzigartiges Phänomen und Musik dramatisches Experiment, Laaber, LaaberVerlag, 2005.

23 E. Weaver, Convent Theatre, pp. 43 and 73-74. 
as extremely worrying ${ }^{24}$. This, however, was not the case. Of the now numerous studies concerning the musical culture of nunneries and convents in the early modern Europe (especially in the Italian Peninsula) ${ }^{25}$, very few contain information about these institutions becoming regular venues for the performance of oratorios. There are more records for the cultivation of theatrical traditions, including even the opera, which, in those cases when costumes were used, provoked the indignation of the ecclesiastical authorities that supervised the female monasteries ${ }^{26}$.

Vienna was one notable exception in this context. At the turn of the $17^{\text {th }}$ and $18^{\text {th }}$ centuries, there were several women-composers of oratorios active in that city. At least one of them, Maria Anna de Raschenau, was a nun at St. Jakob auf der Hülben Augustinian cloister $^{27}$, where

24 This is because eyesight was considered as the sense most susceptible to satanic temptation. Cf. P. Segneri, II Cristiano istruito nella sua Legge. Raggionamenti morali di [...] della Compagnia di Giesu' [sic!], vol. 3, Venezia, Presso Paolo Baglioni, 1690, pp. 237-240.

25 Cf. among others: C.A. Monson (ed.), The Crannied Wall: Women, Religion, and the Arts in Early Modern Europe, Ann Arbor, University of Michigan Press, 1992; C.A. Monson, Disembodied Voices: Music and Culture in an Early Modern Italian Convent, Berkeley-Los Angeles, University of California Press, 1995; R.L. Kendrick, Celestial Sirens: Nuns and Their Music in Early Modern Milan, Oxford, Clarendon Press, 1996; C. Reardon, Holy Concord within Sacred Walls: Nuns and Music in Siena, 15751700, Oxford-New York, Oxford University Press, 2001, J.K. Page, Convent Music and Politics in Eighteenth-Century Vienna, Cambridge, Cambridge University Press, 2014; J.E. Glixon, Mirrors of Heaven Or Worldly Theaters?: Venetian Nunneries and Their Music, Oxford, Oxford University Press, 2017; on Polish nuns and their music cf. M. Walter-Mazur, Musical Culture of Polish Benedictine Nuns in the Seventeenth and Eighteenth Centuries, Eastern European Studies in Musicology, vol. 12, Berlin, Peter Lang, 2018.

26 Page, Convent Music, p. 86 (concerning the carnival play productions at one of Mantua' nunneries in the mid-1 $17^{\text {th }}$ century); Glixon, Mirrors of Heaven, especially chapter 7: A Virtuous Recreation? Musical and Theatrical Entertainments for and by the Nuns.

27 Italian oratorios, performed at the imperial chapel in Vienna, were also written by Camilla de' Rossi, Maria Margherita Grimani, and Caterina Benedicta Grazianini. Little is unfortunately known about their biographies and musical education; we do not have information whether they were members of religious orders. In Bologna, oratorios by composer and painter Angela Teresa Muratori-Scanabecchi were performed in the same period. She was however, at the same time, a wife and the mother of several children; cf. F. Lora, 'Muratori, Angela Teresa', in Dizionario biografico degli Italiani, vol. 77 (2012), https://www.treccani. it/enciclopedia/angela-teresa-muratori_(Dizionario-Biografico)/ (accessed 19 December 2020). in the late $17^{\text {th }}$ and early $18^{\text {th }}$ centuries the nuns regularly performed oratorios written both by their Chormeisterin and by other composers ${ }^{28}$.

Viennese Ursuline nuns likewise sang annual oratorios for the Holy Week and the feast day of their patroness, St Ursula $\left(21^{\text {st }} \text { October }\right)^{29}$. It was the Ursulines who in 1704 performed the oratorio La Giuditta, with words by Pietro Ottoboni and music by the court composer Carlo Agostino Badia ${ }^{30}$. The work's topic fit ideally into this congregation's preference for representations of valiant women in oratorios. All the same, even in this circle a patriarchal element was added, possibly to suit the tastes of the imperial guests. At the end of the spectacle, it is not Judith who elucidates the meaning of that Biblical figure as an allegory of Mary (as she did in some Italian productions of this oratorio, with music by Alessandro Scarlatti); instead, this exegesis is presented by Oziah, governor of Bethulia ${ }^{31}$.

The Habsburgs' kind interest in the musical activity of female monasteries - and sometimes even close links developing between the latter and the court, which liked publicly to demonstrate its piety - certainly provided an additional incentive for the nuns to take up artistic challenges. That interest also served as a kind of protective umbrella in case of criticism being expressed by the church authoritiesin Vienna, which, however, were not as restrictive with regard to monastic music-making as they were in the Italian Peninsula ${ }^{32}$.

In Italian female cloisters after the Council of Trent, which decided about their nearly complete isolation from the outside world, music-making encountered various obstacles. It was decided that music education should

28 For more information, cf. Page, Convent Music, especially chapter 2: Maria Anna von Raschenau and music at the convent of St. Jakob auf der Hülben.

29 For more information, cf. Page, Convent Music, chapter 3: Court, music, and Counter-Reformation education in an Ursuline convent.

30 La Giuditta. Oratorio La Giuditta cantata dalle RR. Madri Orsoline alle sacre cesaree e regie maestà et serenissime altezze nel giorno di S. Orsola dell'anno 1704 posto in musica dal sig. Carlo Agostino Badia compositor in servizio di sua maj. Cesarea, Vienna d'Austria, Andrea Heyinger, [1704].

31 Ryszka-Komarnicka, Księga Judyty, p. 367.

32 Page, Convent Music, p. 79. On especially solemn occasions, the nuns' ensemble could be accompanied by a hired orchestra consisting of trombonists, trumpeters, and timpanists. Priests were likewise employed to sing the bass parts in polyphonic works, in case there was no nun capable of performing in this voice range. Cf. Page, Convent Music, pp. 84-85. 
take place within the walls of the monastery, without employing persons from outside. Any form of nuns' singing, apart from plainchant, could only take place, for the greater glory of God, in the privacy of the cloister. It was not meant as a way of attracting to the church crowds of believers for whom the opportunity to listen to spectacular music in excellent interpretations sometimes proved more important than an attentive focus on the liturgy. These recommendations were to be implemented by the local bishops, whose attitudes to the question of music-making in female monasteries were different. Since the high-and-mighty forced the surplus of their female progeny to spend their lives in the cloisters, they made sure that the fetters of monastic discipline should not be too heavy or too tiresome for them. They thus exerted pressure on the authorities to evade all these imposed restrictions ${ }^{33}$. They also wanted to make sure that the ceremony of their family member entering a religious order should receive as impressive a setting as possible.

\section{DRAMATIC WORKS WITH MUSIC ACCOMPANYING THE CEREMONY OF ENTERING THE MONASTERY- A PRELIMINARY SURVEY}

The religious rites of entering the novitiate (the clothing or 'reception') and of taking the monastic vows (the profession) had their own separate dramaturgy. Preparations took plenty of time and could also involve additional music training, which allowed the candidates to participate in a fully professional manner in all the required singing. Masses were celebrated on such occasions by church dignitaries and accompanied by 'festive music', which involved not only liturgical pieces, but also instrumental concerti and sinfonie $e^{34}$. The monastic churches were richly decorated for such occasions. Poems commemorating these events were printed; countless occasional prints comprising such poetry can be found

33 For more on this subject, cf. C.A. Monson, Nuns Behaving Badly. Tales of Music, Magic, Art, and Arson in the Convents of Italy, Chicago, The University of Chicago Press, 2010, especially chapter 4: Perilous Patronage: Generosity and Jealousy, Santa Maria Nuova (Bologna, 1646-80). Cf. also K. Montford, 'L'Anno santo and Female Monastic Churches: The Politics, Business and Music of the Holy Year in Rome', Journal of SeventeenthCentury Music, vol. 6, no. 1, 2000, http://www.sscm-jscm.org/ v6/no1/montford.html (accessed 16 December 2020), par. 3.5.

34 Glixon, Mirrors of Heaven, especially chapter 4: Transitions. in Italian archives. These festivities attracted the families as well as representatives of notable families from the area. In some cases, all the participants were granted an indulgence concerning a specified number of days ${ }^{35}$.

The extra liturgical celebrations of these events could include allegorical rappresentazioni. One such piece, entitled Nel monacarsi della Signora N.N., was left behind by an aristocratic poet, Count Fulvio Testi (d. 1646). It is a brief versified dramatic 'scene', complete with footnotes which point to psalm verses (mostly the Song of Songs, which played a major role in the clothing ceremony). The protagonists' words (two Angels, Bride and Bridegroom) are Italian poetic paraphrases of the psalm lines ${ }^{36}$. As the music theatre entered its heyday, the clothing and profession ceremonies began to be accompanied by sung rappresentazioni, and later by oratorios ${ }^{37}$. Owing to the high costs and substantial effort involved in their organisation, such events were rarer, and thus also considerably fewer records of them (in the form of scores and/or libretti) have survived, in comparison with the number of occasional poems. I have been able to trace more than thirty such $17^{\text {th }}$ - and $18^{\text {th }}$-century works (cf. the selection in the Appendix), and have found evidence that the living tradition continued into the following century. An especially large number of such pieces originate in Bologna, Cesena, Florence, Iesi, and Naples. It needs to be emphasised that they have not been the subject of any scientific study to date. It will therefore be worthwhile to attempt an at least general overview of this output.

Two categories can be distinguished within this repertoire: allegorical cantatas, and oratorios based either on selected Old Testament stories or on saints' lives. Division by theme proves even more informative. There are two basic subjects. The first focuses on the wedding, conceived both allegorically (as the mystical union of the soul with the divine bridegroom) and in Biblical terms (where the heroine is a prefiguration of Mary, as in the oratorios about Abigail and David, Bathsheba and David, Ruth and Boaz, Rachel and Jacob, or Esther and Ahasuerus). The second group stresses fides and fortitudo as the two main virtues which need to characterise a woman entering monastic life. This topic could again be

35 E. Novi Chiavarra, Sacro, publico e privato. Donne nei secoli XV-XVIII, Napoli, Alfredo Guida, 2009 (especially Rituali di monacazione, pp. 31-42).

36 F. Testi, Terza Partadelle Poesie del Signor Conte Don [...], Modena, Per Bartolomeo Sogliani, 1651, pp. 155-158.

37 Smither, A History, pp. 29-30. 
presented either in the allegorical convention or through Old Testament stories and saints' lives.

Hagiographical oratorios (such as those of St Agatha the Martyr and St Philip Neri) are scarce, possibly because such subjects were no longer fashionable in the $18^{\text {th }}$ century. The Old Testament oratorios can be further subdivided into two groups. One consists of stories of unconditional obedience to God resulting from profound faith (Abraham and Isaac, Jephthah and his daughter, the death of Abel). Symptomatically, proof of faith and obedience is offered in these tales not only by the children, but first and foremost by their parents. We can therefore view these oratorios as a kind of homage to the parents of the young novices and nuns, since they represent the act of sending a daughter to a monastery as a valiant sacrifice, dear to God. The second group is made up of tales in which faith and fortitude lead to a glorious triumph. Prominent among the latter are the stories of extraordinary women: Deborah, Jael, and Esther who saved the Israelites; Susanna, and - on as many as five occasions $^{38}$ - also Judith.

The Book of Judith was a major source of inspiration for dramatic works, since her story was viewed as an analogy to consecrated life. Giovanni Paolo Oliva, Superior General of the Jesuits, emphasised her dedication to prayer, fasting, and penance following her husband's death. All this toughened up her spirit and let her overcome her weakness when, dressed in festive clothes, she arrived at Holofernes' camp, aroused his lust, and still managed to return to her native city not only without a blemish on her honour, but with the cut-off head of her enemy. Observing all the rules of consecrated life is of paramount importance; strict as they are, they render the religious immune to temptations ${ }^{39}$. This is what makes Judith into a model for nuns to emulate. Another preacher, Evangelista Da Momigno, based the first of his three sermons for the clothing of novices entirely on a comparison of the stages by which Judith prepared to defeat the enemy to the key symbolic elements and

38 One of the libretti was inaccessible in the period of my work on this paper: La Giuditta. Dialogo a quattro voci da cantarsi nel venerabile Monistero di S. Giovanni l'Origlione in occasione prende l'abito del glorioso S. Benedetto la signora D. Giovanna Bosco, e Lanza de' principi di Belvedere sotto il felice governo della rev. madre abbadessa la signora Soro Vincenza Margarita Abbate, Palermo, nella stamperia de' Poveri di Gesù Cristo presso Angelo Felicella, 1752.

39 G.P. Oliva, Sermoni domestici detti privatamente nelle Case Romane della Compagnia di Giesù [...], vol. 1, Roma, Per II Varese, 1670, pp. 211-212. gestures of the clothing ceremony ${ }^{40}$. Thus, as Judith, who lived a life of chastity, changed from mourning to festive clothes, so also the candidates for the novitiate put on new clothes which were a sign of their spiritual transformation. As Judith carefully brushed her hair and tidied it, so they had their hair cut, which symbolised submission to the will of God. Finally, as Judith reached for a sword to defend her fatherland, so the young novices received crosses as weapons in their struggle with the devil.

\section{a) La Giuditte (Bologna 1621)}

This is the earliest of the Judith plays for entering the monastery that I have been able to identify. It is also one of the earliest theatrical works in all of music history meant to be sung in their entirety, which makes the fact of its score now being lost the more regrettable, even though its authors' names do not tell us much nowadays ${ }^{41}$. From the preface we learn it was specially written for the Dominican Nuns of St Mary Magdalen (so named after the patron of their church). In that text, the nuns apologise to the author, should their performance prove not to live up to his expectations, and accept the blame for all the imperfections ${ }^{42}$. Does this mean that they sang the rappresentazione themselves? This is likely, though we have no specific information about music life in this monastery ${ }^{43}$. The spectacle was dedicated to Bolognese

40 E. Da Momigno, Direttorio de' Superiori Regolari, et Ecclesiastici, che hanno governo di Frati, e di Monache [...], Venetia, Presso Gio: La Noù 1657, pp. 439-447.

41 The practise flourished at that time in Florence and Rome. It may have been introduced in Bologna by Jacopo Cicognini, at least one of whose sacre rappresentazioni was meant for musical performance, II martirio di Sant'Agata, was written (as the author himself confirms) in Bologna (1614), though it was probably not staged there. Cf. J. Cicognini, II Martirio di S.a Agata, rappresentazione spirituale del Dot. [...] Academico Incostante, Firenze, Appresso I Giunti, 1624, see A i cortesi lettori). Rappresentazioni dominated in the Bolognese nonliturgical sacred music repertoire until the mid-17 $7^{\text {th }}$ century; cf. V. Crowther, The Oratorio in Bologna (1650-1730), Oxford, Oxford University Press, 1999, pp. 42-43.

42 La Giuditte. Rappresentazione spirituale di Francesco Georgio Bolognese. Composta in Musica dal Sig. Lorenzo Righetti [...], Bologna, gli eredi di Bartolomeo Cochi, p. 3.

43 There is also no trace of any other works that might prove the continuity of the rappresentazioni performance tradition in that particular monastery. There may have been no such continuity in fact, since in that period another Bolognese female cloister, S. Cristina della Fondazza, entered into a fierce dispute with the 
ladies, which shows that the profession ceremony of Maria Gabriella Vergili only served as a pretext for the presentation of this work. The initiative must have come from the monastic congregation, rather than from the Vergili family, which was not part of the local aristocracy. The preface also emphasises the union of two worlds, secular and monastic, both of which, albeit in different ways, aimed to cultivate the virtues necessary for salvation. The Dominican nuns declare they will constantly pray for their secular sisters.

The aim of the spectacle was, therefore, to manifest the monastery's presence and major role in the city's life ${ }^{44}$. This determined the way the Biblical story was presented. The play, of rather modest dimensions (three acts of three scenes each, plus a prologue presented, adequately to the occasion, by the allegorical figure of Chiesa trionfante, and the so-called anteproscenio depicting the threat that the Assyrian invasion posed for the Jewish lands), focuses on ardent faith in Jehovah's protection. This faith is shared not only by Judith and her loyal maidservant, but also by Achior the Ammonite, Oziah and other priests, who pray for the valiant woman (in Act 1, Scene 1). What the play does, therefore, is omit the fact of the Bethulians being shaken in their faith, which aroused Judith's indignation, and which is crucial to the religious message of the Book of Judith. Since the context of the spectacle in a way identified Bethulia with Bologna, the presentation of the elders and priests in La Giuditte had to be positive, even at the expense of passing over some facts known from the Biblical tale (in accordance with the popular Baroque strategy of dissimulazione onesta). The choice of the target audience likewise made the

church authorities, which attempted to control the congregation as strictly as possible. Music and its role in monastic life was one of the key bones of contention in this debate (for more information, cf. C.A. Monson, Divas in the Convent. Nuns, Music and Defiance in Seventeenth-Century Italy, Chicago, University of Chicago Press, 1995).

44 Performances of rappresentazioni and oratorios played an analogous function in the activity of secular fraternities, cf. J. Riepe, "'Per Gloria del nostro Santissimo Protettore, per la propria divotione, e per honore della compagna." Osservazioni sulle esecuzioni di oratori delle confraternite in Italia nel XVII e XVIII secolo', in P. Besutti (ed.), L'Oratorio musicale italiano e i suoi contesti (Secc. XVII-XVIII). Atti del convegno internazionale. Perugia, Sagra Musicale Umbra, 18-20 settembre 1997, Firenze, Leo S. Olschki Editore, 2002, pp. 341-364. These fraternities, as the lay counterparts of religious orders, sometimes commemorated the reception of new members with spectacles of rappresentazioni or of oratorios; Riepe, "'Per Gloria del nostro..."', pp. 345-346. authors place emphasis on scenes featuring the heroines, Judith and Abra (Scene Two of the successive acts) and on the final scene in which Bethulian girls sang and danced in honour of the victorious woman (Act 3, Scene 3). Present-day readers may be surprised by the misogynous monologue of Bagoas, Holofernes' eunuch (Act 2, end of Scene 3, and Act 3, Scene 1). Still, the presence of complaints about the fair sex's unstable and insidious nature in a work most probably dedicated to and performed by women - was nothing unusual in that period. It fitted well into the character of the then querelle de femmes, as well as introducing a comic element which belonged to the theatrical tradition. For the church authorities at least, the final dance may have been far more worrying, since it was typical of rappresentazioni staged at courts. Dance entertainment was supposed to be banned from monastic space, though this rule did not always work in practice.

\section{b) Giuditta (Padua 1735)}

An equally interesting Judith oratorio was performed more than a hundred years later at Padua's monastery of Poor Clares known as Beata Elena (after the church where the venerated mortal remains of Blessed Elena Enselmini, a $13^{\text {th }}$-century Franciscan nun were then kept). The anonymous libretto author strove to emphasise the valour, piety, and chastity of the eponymous heroine. In the process of doing so, some significant alterations were introduced in comparison with the plot of the Book of Judith. One may even receive the impression that the fact of the oratorio being dedicated to as many as three female representatives of the honourable Vignola family ${ }^{45}$ made the author exaggerate the virtues of the heroine, who was to serve as a representation of his dedicatees' virtues.

Thus, in the first part, as soon as Judith and Abra have arrived at Holofernes' camp, the commander intends to sentence them to death. It is only after a longer while that he yields to the charm of the beautiful Jewess (with some help from Bagoas rather comically tempting him). In part two, on the other hand, Judith has prayed for so

45 Giuditta. Oratorio per musica da rappresentarsi nell'occasione che L'Illustrissima Signora Pellegrina Vignola Cittadina Veneta, e Nobile Padovana prende l'abito religioso nell'insigne, ed esemplare Monastero della Beata Elena di Padova; consagrato al merito singolarissimo della Reverendissima Madre S.R Maria Rosa Abbadessa, e S.R Maria Girolama Vignola Zie Reverendissime della Sudetta, Padova, Gio: Battista Conzatti, 1735. 
long that, on arriving at Holofernes' tent for the feast, she already finds him drunk on wine and asleep. The librettist follows Aristotle's precepts for the drama in not showing the Assyrian chieftain's death on stage. The audience is only treated to Judith's succinct account of her own deed as she passes the enemy's head on to her maidservant. This allows the author to get Judith out of direct participation in the most ambiguous scenes of the Book of Judith, such as talking to a lustful male, taking part in a boozy feast, and slaughtering the enemy. This does not mean, however, that the solemn tone is maintained throughout the libretto. I have already signalled some departures from the lofty mode, such as Bagoas' role in the 'scene' of Holofernes' first meeting with the guests from Bethulia. Both Bagoas' and Abra's (Judith's servant's) roles are unusually well developed here. The most interesting scene featuring these two comes at the start of part two, where Bagoas arrives with the invitation to the feast to be held at Holofernes' tent. Abra assures him that her mistress, who is a model of chaste and timid modesty, would never agree to take part in such an event. The eunuch banters with her, questioning Judith's virtues, and arguing that a solitary escapade to the enemy's camp in festive clothes surely did not become a woman who had a sense of selfrespect. Elements of the querelle de femmes thus again come to the fore in the form of a dispute about what is becoming or unbecoming in a woman, conducted in a tone which is humorous or even comic.

Such solutions might be considered, on the one hand, as relics of the tradition of carnival comedy productions shown in monasteries, and on the other, in the context of the period when this oratorio was composed, as an echo of the scene buffe, intermezzi, and the increasingly popular commedie in musica. The question remains open whether these scenes are unique in the entire oratorio repertoire related to the ceremonies of entering monastic life ${ }^{46}$. Be it as it may, in the context of the other Judith oratorios the Paduan Giuditta is a puzzling case indeed. It appeared, after all, barely a year after the publication in Vienna of Metastasio's extremely solemn La Betulia liberata, marking the crowning point in the process of purging

46 Comic elements can be found in the oratorio La resurezione di Giesu Cristo, performed by the Viennese Ursulines, with music by C.A. Badia (1702), which starts with the mocking lament of a Soldier keeping nightly watch over the Holy Sepulchre, who complains about the hardships of military service. Cf. La resurezione di Giesu Cristo Oratorio da cantarsi dalle RR.MM. Orsoline nella sera del sabbato santo al Santo Sepolcro. Posto in musica dal sig. Carlo Agostino Badia virtuoso di camera di s.m.c., Vienna d'Austria, Andrea Heyinger, 1702.
Baroque libretti based on this story from all erotic and trivial elements, which manifested itself, among others, in removing the servant characters (similarly as in the opera seria following Zeno and Metastasio's reform). One cannot help getting the impression that the comic elements were 'smuggled' into the Paduan spectacle, most likely arranged by the Vignola family, in order for the dedicatees both to receive the due homage and, together with their monastic companions, to get a little taste of the entertainment from which they were likely barred in their everyday lives.

\section{c) La Betulia liberata with music by Pasquale Cafaro (1746) and Giuditta (Florence 1750)}

About a dozen years later, the poeta cesareo's oratorio was chosen to celebrate the monastic vows of Maria Teresa Francone. In this case, a handwritten score of Pasquale Cafaro's (1715-1787) music has been preserved. We know the date of composition $(1746)^{47}$, but the manuscript contains no information as to the monastery and congregation for which it was written, and there is no printed libretto for this ceremony. Taking into account the composer's place of work and residence, however, as well as the seat of the noble family of Francone, we may assume that Maria Teresa entered one of the numerous monasteries situated in Naples ${ }^{48}$. Metastasio's Judith, with her virtues of constantia and fortitudo, represented an allegory of the Habsburg dynasty and its current representative, Charles VI. Cafaro's music maintains this solemn tone, and faithfully follows the original text. It is scored for 6 soloists (3 sopranos, alto, tenor, and bass), who also substitute for a choir in the ensemble scenes. They are accompanied by a rather large orchestra consisting of a string section with basso continuo as well as oboes, horns, and trumpets. The arias are long, demanding in terms of both technique and expression, worthy of a performance by professional singers. They are separated by diffuse recitatives typical of Metastasio's oratorios and operas. Cafaro's settings of these sections are extremely careful (several of them are recitative accompagnati), only

47 La Betulia Liberata del Sigr: Pasquale Cafaro. Sacro Dramma Per la Monacazione dell'Ecc ${ }^{m a}: S^{r a}$ : D. Ma: Teresa Francone.

48 The main seat of the family was in Naples, but they also possessed vastlanded estates in the Province of Lecce, where the composer came from; cf. G. Recchio, Notizie di Famiglie Nobili, ed Illustri della Città, e Regno di Napoli. Descritte da Don [...], Napoli, 1717, pp. 62-63. 
slightly and occasionally abbreviated in comparison with the original libretto. Judith's crucial aria 'Parto inerme, e non pavento' represents the majestic and pompous style of the so-called aria di portamento (Largo, Alla breve, in A major), similarly as in the first setting of this text by Georg von Reutter Jr.

Abate Francesco Grazzini likewise followed Metastasio's libretto closely in his modestly scored but similarly solemn componimento drammatico entitled Giuditta, which features two main parts, those of Judith and $\mathrm{Oziah}^{49}$. It was set to music by the now little known Niccolò Santini. The costly (bi-coloured) 1750 edition of the libretto was complemented by sonnets which praised Lucretia Nerli on her entering the monastery of the Florentine Dominican nuns. The first of these poems, signed 'Dell'Illustriss. Signor G.P.', develops ideas from the libretto, quoting the examples of Judith, Jael, and Esther, which the novice taking part in the clothing ceremony was to follow in her life ${ }^{50}$.

\section{CONCLUSIONS AND SUGGESTIONS FOR FURTHER RESEARCH}

We should finally examine where and in what manner the performances of oratorios for the clothing and profession ceremonies were held. The printed libretti (which constitute the majority of our sources, cf. the selected titles listed in the Appendix) do not always provide clear and sufficient clues in this respect. Further research may provide us with new information on this subject.

In the current state of research, we may hypothesise that these performances usually took place in the monastic churches, where they could be heard by both the guests and the nuns separated from them by the bars of the choir gallery. The interval between the parts was likely used for the sermon (as during the esercizi spirituali). This is confirmed by the printed libretto of Lo sposalizio di Rachele con Giacobbe for the clothing ceremony held at Padua's Benedictine nunnery in $1729^{51}$.

49 Giuditta. Componimento drammatico da cantarsi per lo solenne ingresso nel venerabile Monastero di Santa Caterina in Via Larga dell'llustrissima Signora Lucrezia Nerli [...], Firenze, Andrea Bonducci, 1750.

50 Giuditta. Componimento..., p. XVII.

51 Lo sposalizio di Rachele con Giacobbe. Componimento sacro per musica da rappresentarsi nell'occasione che prendono l'abito religioso di S. Benedetto le Nobili Signore Contessa Paola,
The music itself was most likely executed by hired male musicians (since performances by the nuns and novices themselves would have been noted in monastic records). The few surviving scores require varied performing forces, from high-pitched voices to tenors and basses (as in Cafaro's Betulia liberata discussed above). This is also corroborated by the much earlier allegorical dialogue written by Alessandro Stradella for the clothing ceremony of Angelica Lanzi (birth name: Lante della Rovere) at Rome's Dominican monastery of SS Domenico e Sisto $(1675)^{52}$, which comprises the following solo parts: Maria Christina (soprano), Carne (Body, alto), Mondo (The World, tenor), and Demonio (Devil, bass) ${ }^{53}$. It was an exceptional event for Rome, where any kind of 'external' music performances in female cloisters had been banned already ten years earlier ${ }^{54} .1675$ being the Jubilee Year, when religious events were celebrated with great pomp so as to dazzle the pilgrims flocking into the Eternal City, these strict regulations were temporarily suspended ${ }^{55}$.

The above-presented theses are also proved, in a rather subversive manner, by another surviving score; that of the allegorical operina sacra staged in 1686 for the admission to the monastery of Donna Olimpia Chigi in Siena. The three soprano parts, those of Amor Divino (Divine Love), Innocenza (Innocence), and Diletto (Pleasure), were sung on that occasion by female children, including Olimpia's two younger sisters ${ }^{56}$, who were not nuns (though they would become ones later), but who stayed at St Hieronymus monastery as pupils (the so-called educande). The vocal parts correspond to their performers' limited skills, though admittedly their vocal abilities were considerable for their age, and they likely owed them to their monastic education. As evident

e Co: Giustina De Lazzara nel celebre Monastero di San Stefano in Padova [...] Dedicato al merito singolare dei Nobili Signori Co: Giovanni, e co: Emilia De Lazzara amatissimi Genitori delle Suddette [...], Padova, per il Penada, 1729, pp. 10-19.

52 C. Gianturco, Alessandro Stradella, 1639-1682: His Life and Music, Oxford, Clarendon Press, 1994, p. 223.

53 A. Stradella, Dialogo in La per monacazione di Angelica Lanzi Romana, Pugna certamen militia, a 4 voci, violini 1.i e 2.i, viole e organo.

54 Montford, 'L'Anno Santo', par. 3.3-3.4.

55 Montford, 'L'Anno Santo', par. 4.2.

56 Operina sacra in Musica a 3 co' Wiolini, rappresentata in occasione che prende l'Abito Francescano nel Venerabi.e Monaste.o di S. Girolamo ditto Campanzi di Siena L'Eccellentissima Signora Principessa D. Olimpia Chigi L'Anno1686. 


\section{sciendo}

from this example, though music-making and musical education at female cloisters represented a high standard, nuns' 'public' singing and playing (including from the barred choir gallery) was unacceptable, even during such a prestigious ceremony. That the young pupils were granted this privilege was most likely the result of pressure from their titled relatives, who had included the recently deceased pope Alexander VII ${ }^{57}$. Efforts to eliminate 'worldly' music from female cloisters, or at least from those performances which could be heard by all the faithful present in the church, seem to have brought such fruit as the church authorities wished for.

The subject matter of the plays accompanying clothing and profession ceremonies was usually selected very carefully. The oratorio libretti, or at least those based on Old Testament themes, should be studied in more detail by researchers in order to find out to what extent the tales and their heroines (as in the case of most of the Judith plays) were adapted and moulded by the librettists specially with these monastic ceremonies in mind. The possible presence and frequency of comic themes in these works should also be examined.

Performances of oratorios celebrating members of powerful families entering the monastery represent a specific type of event, suspended between the cloistered and secular life and worlds. While they honoured the heroines of the former, the organisation of the spectacles themselves, and the content they sometimes included (especially in the case of works based on Old Testament subjects), clearly belonged to the latter.

\section{MUSICAL SOURCES (CITED)}

Dialogo in La per monacazione di Angelica Lanzi Romana, Pugna certamen militia, a 4 voci, 2 vni, vle, organo, mus. A. Stradella (manuscript copy in I-Moe, mus.f.1126).

La Betulia Liberata del Sigr: Pasquale Cafaro. Sacro Dramma Per la Monacazione dell'Ecc ${ }^{m a}$ : Sig ${ }^{r a}$ : D. $M^{a}$ : Teresa Francone, vols. I-II (manuscript copy in I-Fn, MS-1661 (2)).

Operina sacra in Musica a 3 co' Wiolini, rappresentata in occasione che prende l'Abito Francescano nel Venerabi.e Monaste.o di S. Girolamo ditto Campanzi di Siena L'Eccellentissima Signora Principessa D. Olimpia Chigi L'Anno 1686 (manuscript copy in I-Rvat, Chigi Q VI 84).

57 Reardon, Holy Concord..., pp. 131-153.
Italian 17th-and 18th-Century Dramatic Works with Music, Written for the Clothing and Profession Ceremonies, with Special Reference to Compositions Based on the Book of Judith

\section{PRINTED LIBRETTI (CITED)}

Giuditta. Componimento drammatico da cantarsi per lo solenne ingresso nel venerabile Monastero di Santa Caterina in Via Larga dell'illustrissima Signora Lucrezia Nerli col nome di suor Teresa Eletta Mariana Caterina, Firenze, Andrea Bonducci, 1750.

(Il) Martirio di S. ${ }^{a}$ Agata Rappresentazione del Dot. Iacopo Cicognini Accademico Incostante. Dedicata All'ill. ${ }^{\text {mo }}$ Sig. ${ }^{r}$ Cav. ${ }^{\text {er }}$ Andrea Cioli Segretario di Stato del Serenissimo Gran Dvca Di Toscana, \& Gran Cavalliero Dell'illustrissima, \&Sacra Religione di S. Stefano, Firenze, Appresso I Giunti, 1629.

(La) Giuditta. Dialogo a quattro voci da cantarsi nel venerabile Monistero di S. Giovanni l'Origlione in occasione prende l'abito del glorioso S. Benedetto la signora D. Giovanna Bosco, e Lanza de' principi di Belvedere sotto il felice governo della rev. madre abbadessa la signora Soro Vincenza Margarita Abbate, Palermo, nella stamperia de’ Poveri di Gesù Cristo presso Angelo Felicella, 1752.

Giuditta. Oratorio per musica da rappresentarsi nell'occasione che L'Illustrissima Signora Pellegrina Vignola Cittadina Veneta, e Nobile Padovana prende l'abito religioso nell'insigne, ed esemplare Monastero della Beata Elena di Padova; consagrato al merito singolarissimo de la Reverendissima Madre S. ${ }^{R}$ Maria Rosa Abbadessa, e S. ${ }^{R}$ Maria Girolama Vignola Zie Reverendissime della Sudetta, Padova, Gio: Battista Conzatti, 1735.

(La) Giuditta. Oratorio La Giuditta cantato dalle RR. Madri Orsoline alle sacre cesaree e regie maestà et serenissime altezze nel giorno di S. Orsola dell'anno 1704 posto in musica dal sig. Carlo Agostino Badia compositor in servizio di sua maj. Cesarea, Vienna d'Austria, Andrea Heyinger, [1704].

(La) Giuditta. Oratorio da rapresentarsi nella Chiesa di S. Leonardo in Padova l'anno 1713 essendo presidente la nobil signora Laura d'Este della Congregazione della Santissima Annonziata, Padova, il Penada, [1713].

(La) Giuditte. Rapresentatione spirituale di Francesco Georgio bolognese, composta in musica dal sig. Lorenzo Righetti ad istanza delle molto rr. monache di S. Maria Maddalena di Bologna nella professione della reverenda suor Maria Gabriella Vergilj, nel loro Monastero, Bologna, gli eredi di Bartolomeo Cochi, 1621.

(La) resurezione di Giesu Cristo. Oratorio da cantarsi dalle RR.MM. Orsoline nella sera del sabbato santo al Santo Sepolcro. Posto in musica dal sig. Carlo Agostino Badia virtuoso di camera di s.m.c., Vienna d'Austria, Andrea Heyinger, 1702. 


\section{sciendo}

(La) Sposa de cantici piamente considerata nella diletta consorte di Gesù appassionato S. Catarina da Siena domenicana. Dialogo per musica da cantarsi nella chiesa di Sant'Agostino de PP. Predicatori. Consacrato alle nobilissime dame della congregazione di detta santa, essendo presidente la nobil signora Elena Maria Descalzi, Padova, Corona, 1706.

(Lo) Sposalizio di Rachele con Giacobbe. Componimento sacro per musica da rappresentarsi nell'occasione che prendono l'abito religioso di S. Benedetto le nobili signore contessa Paola e co. Giustina de Lazzara nel celebre Monistero di San Steffano in Padova l'anno 1729. Dedicato al merito singolare dei nobili signori co. Giovanni e co. Emilia de Lazzara amantissimi genitori delle suddette, dalle nobili signore Bomartini, Padova, per il Penada, 1729.

\section{REFERENCES}

Arnold, D., 'Orphans and Ladies: the Venetian Conservatoires (1680-1790)', in Proceedings of the Royal Musical Association, 1962-1963, pp. 31-47.

Baldauf-Berdes, J.L., Women Musicians of Venice. Musical Foundations, 1525-1855, Oxford, Clarendon Press, 2004.

Black, Ch.F., Italian Confraternities in the Sixteenth Century, Cambridge, Cambridge University Press, 1989.

Borsetto, L., 'Trionfante e vittoriosa. Icone di Giuditta nell'epica del Seicento', in L. Borsetto (ed.), Giuditta $e$ altre eroine bibliche tra Rinascimento e Barocco. Orizzonti di senso e di genere, variazioni, riscritture. Atti del Seminario di Studio (Padova, 10-11 dicembre 2007), Padova, Padova University Press, 2011, pp. 75-98.

Ciletti, E., 'Judith Imagery as Catholic Orthodoxy in Counter-Reformation Italy', in K.R. Brine, E. Ciletti and H. Lähnemann (eds), The Sword of Judith. Judith Studies Across the Disciplines, Open Book Publishers, 2010, pp. 345-368.

Ciletti, E. and Lähnemann, H., 'Judith in the Christian Tradition', in K.R. Brine, E. Ciletti and H. Lähnemann (eds), The Sword of Judith. Judith Studies Across the Disciplines, Open Book Publishers, 2010, pp. 41-65.

Cosentino, P., Le virtù di Giuditta. Il tema biblico della 'mulier fortis' nella letteratura del '500 e del '600 (Dulces Musae. Collana di Studi e Testi di Letteratura Italiana, 7), Roma, Aracne Editrice, 2012.

Crowther, V., The Oratorio in Bologna (1650-1730), Oxford, Oxford University Press, 1999.
Italian 17th-and 18th-Century Dramatic Works with Music, Written for the Clothing and Profession Ceremonies, with Special Reference to Compositions Based on the Book of Judith

Da Momigno, E., Direttorio de' Superiori Regolari, et Ecclesiastici, che hanno Governo di Frati, e di Monache: Dove si contengono Ottanta Sermoni, Motivi, Istruttioni, \&Formule, appartenenti alle funtioni di detti Superiori Opera utile anco [sic!] per Confessori di Monache, et per tutti li Predicatori. Composto per R.M.P. F. Evangelista Da Momigno de Min. Oss. di S. Francesco della Provincia di Toscana, Lettore Giubilato, Predicatore Clarissimo, orgià nella Cismontana Famiglia Vicario Generale, e Ministro Provinciale. Dedicato al Reverendissimo Padre D. Antelmo Gravise Degnissimo Priore della Certosa di Vedana, e già altre volte di Venetia, Padoa, Montelo, Erc. Venetia, Presso Gio: La Noù, 1667.

Gallo, V., 'Giuditta sulla scena italiana tra Cinque e Seicento', in L. Borsetto (ed.), Giuditta e altre eroine bibliche tra Rinascimento e Barocco. Orizzonti di senso $e$ di genere, variazioni, riscritture. Atti del Seminario di Studio (Padova, 10-11 dicembre 2007), Padova, Padova University Press, 2011, pp. 99-121.

Garrard, M.D., Artemisia Gentileschi. An Image of the Female Hero in Italian Baroque Art, Princeton, New Jersey, Princeton University Press, 1989.

Geyer, H., Das Venezianische Oratorium 1750-1820: Einzigartiges Phänomen und Musikdramatisches Experiment, vols. 1-2, Laaber, Laaber-Verlag, 2005 (Analecta Musicologica 35/1-2).

Gianturco, C., Alessandro Stradella, 1639-1682: His Life and Music, Oxford, Clarendon Press, 1994.

Glixon, J.E., Mirrors of Heaven Or Worldly Theaters?: Venetian Nunneries and Their Music, Oxford, Oxford University Press, 2017.

Harness, K., Echoes of Women's Voices: Music, Arts and Female Patronage in Early Modern Florence, ChicagoLondon, The University of Chicago Press, 2006.

Harness, K., 'Judith, Music, and Female Patrons in Early Modern Italy', in K.R. Brine, E. Ciletti and H. Lähnemann (eds), The Sword of Judith. Judith Studies Across the Disciplines, Cambridge, Open Book Publishers, 2010, pp. 371-383.

Kendrick, R.L., Celestial Sirens: Nuns and Their Music in Early Modern Milan, Oxford, Clarendon Press, 1996.

Levine Gera, D., 'Introduction', in: D. Levine Gera (intr., ed. and comm.), Judith, Berlin-Boston, De Gruyter, 2014.

Llewellyn, K.M., Representing Judith in Early Modern French Literature, London, Routledge, 2016.

Lora, F., 'Muratori, Angela Teresa', in Dizionario biografio degli Italiani, vol. 77, 2012, https://www.treccani.it/ enciclopedia/angela-teresa-muratori_(DizionarioBiografico)/ (accessed 19 December 2020). 
Monson, C.A. (ed.), The Crannied Wall: Women, Religion, and the Arts in Early Modern Europe, Ann Arbor, University of Michigan Press, 1992.

Monson, C.A., Disembodied Voices: Music and Culture in an Early Modern Italian Convent, Berkeley-Los Angeles, University of California Press, 1995.

Monson, C.A., Divas in the Convent. Nuns, Music, and Defiance in Seventeenth-Century Italy, Chicago, University of Chicago Press, 1995.

Monson, C.A., Nuns Behaving Badly. Tales of Music, Magic, Art, and Arson in the Convents of Italy, Chicago, The University of Chicago Press, 2010.

Montford, K., 'L'Anno santo and Female Monastic Churches: The Politics, Business and Music of the Holy Year in Rome', Journal of Seventeenth-Century Music, vol. 6, no. 1, 2000, http://www.sscm-jscm.org/ v6/no1/montford.html, (accessed 19 December 2020).

Morelli, A., "'Un bell'oratorio all'uso di Roma”: Patronage and Secular Context of the Oratorio in Baroque Rome', in C. Reardon and S. Parisi (eds), Music Observed: Studies in Memory of William C. Holmes, Michigan, Warren, 2004, pp. 333-351.

Novi Chiavarra, E., Sacro, publico e privato. Donne nei secoli XV-XVIII, Napoli, Alfredo Guida, 2009.

Oliva, G.P., Sermoni Domestici detti privatamente nelle Case Romane della Compagnia di Giesù da Gio. Paolo Oliva, Generale della stessa Compagnia. Parte Prima, Roma, Per Il Varese, 1670.

Page, J.K., Convent Music and Politics in EighteenthCentury Vienna, Cambridge, Cambridge University Press, 2014.

Pelliccia, G. (ed.), Anfossi Pasquale, Betulia liberata, Roma, MOS edizioni, 2008.

Reardon, C., Holy Concord within Sacred Walls: Nuns and Music in Siena, 1575-1700, Oxford-New York, Oxford University Press, 2001.

Recchio, G., Notizie di Famiglie Nobili, ed Illustri della Città, e Regno di Napoli. Descritte da Don Giuseppe Recchio, Napoli, Presso Domenico Antonio, e Nicola Parrino, 1717.

Riepe, J., "'Per Gloria del nostro Santissimo Protettore, per la propria divotione, e per honore della compagna." Osservazioni sull eesecuzioni di oratori delle confraternite in Italia nel XVII e XVIII secolo', in P. Besutti (ed.), L'Oratorio musicale italiano e i suoi contesti (Secc. XVII-XVIII). Atti del convegno internazionale. Perugia, Sagra Musicale Umbra, 18-20 settembre 1997, Firenze, Leo S. Olschki Editore, 2002, pp. 341-364 (Quaderni della Rivista Italiana di Musicologia, 35).
Riepe, J., 'Jenseits des Betsaals. Oratorienaufführungen im Profanen Kontext im Italien des 17. und 18. Jahrhunderts', Händel Jahrbuch, vol. 55, 2009, pp. 23-64.

Riepe, J., Die Arciconfraternita di S. Maria della Morte in Bologna. Beiträge zur Geschichte des italienischen Oratoriums im 17. und 18. Jahrhundert, PaderbornMünchen, Ferdinand Schöningh, 1989.

Ryszka-Komarnicka, A., Ksiega Judyty w oratoriach wtoskich epoki baroku [The Book of Judith in Italian Baroque Oratorios], Warszawa, Instytut Muzykologii UW, 2017.

Segneri, P., Il Cristiano Istruito nella sua Legge. Ragionamenti Morali di Paolo Segneri della Compagnia di Giesu'. Parte Terza, Venezia, Presso Paolo Baglioni, 1716.

Smither, H.E., A History of the Oratorio, vol. 3: The Oratorio in the Classical Era, Oxford, Clarendon Press, 1987.

Stocker, M., Judith. Sexual Warrior. Women and Power in Western Culture, New Haven-London, 1998.

Testi, F., Terza Parte delle Poesie del Signor Conte Don Fulvio Testi Commendatore dell'Inoiosa, Modena, Per Bartolomeo Sogliani, 1651.

Walter-Mazur, M., Musical Culture of Polish Benedictine Nuns in the Seventeenth and Eighteenth Centuries, Eastern European Studies in Musicology, vol. 12, Berlin, Peter Lang, 2018.

Weaver, E.B., Convent Theatre in Early Modern Italy: Spiritual Fun and Learning for Women, Cambridge, Cambridge University Press, 2002.

\section{APPENDIX}

Cantatas and oratorios for the ceremony of women entering monastic life (selected works in chronological order; those discussed in the present paper have been listed among the Musical sources and Printed libretti above)

Il martirio di S. Agata oratorio da farsi nella chiesa delle reuerende madri di S. Gabriele in Ferrara dell'ord. carmelitano nel monacarsi la signora Barbara Sacchi dedicato allillustrissimo sig. co. Ercole Estense Mostisindico di ditto monastero posto in musica dal sig. Sebastiano Cherici mastro di cappella della cattedrale, e dellillustrissima academia dello Spirito Santo, Ferrara, per gli eredi del Giglio, 1677.

Oratorio di S. Filippo Neri. Recitato in musica in occasione di monacarsi d'illustrissima signora Vittoria Galli nella Chiesa di S. Nicolò d'Osimo, Ancona, Stamperia Camerale, 1698. 


\section{sciendo}

Lo sponsalizio di Cristo con la Chiesa figurato in quello di Sansone. Oratorio a 4 voci, e più stromenti da cantarsi nella Chiesa del venerabile monistero dell'Immaculata Concezzione per la professione di suor Ignazia Rosalia, $e$ suor Maria Stella Barrera, Rizzo, Trigona, e Grimaldi sotto il governo della reverenda madre su. Anna Vittoria Vintimiglia, abbatessa, Palermo, Antonino Epiro, 1715.

David pentito, oratorio da recitarsi in musica in occasione della professione dalla nobil signora D. Flavia Aurora De Pimbioli nel nobilissimo monastero di S. Steffano di Padova l'anno 1728. Dedicato al merito impareggiabile della nobil signora D. Maria Arcangela de Pimbioli, zia della stessa [...], Padova, per il Penada, 1728.

Cantata a due voci. Del dottor Pini in occasione che l'illustrissima [...] Francesca Crescioni prende l'abito religioso nel [...] Monistero di S. Catarina della città di Cingoli sua patria. Dedicata al [...] monsignor Pietro Secondo Radicati vescovo [...] della città di Cingoli e d'Osimo, Jesi, Gio. Battista de' Giulij, 1729.

La Bersabea, melodrama sagro, in occasione che prende l'abito religioso nel nobilissimo monistero di S. Romualdo di Fabbriano l'illustrissima signora Anna Gionantoni di detta città con inomi di D. Aloisa Costante Romualda Margarita Maria. Parole del sig. Raimondo Mazzanti, musica del sig. Domenico Laurelli, Fabbriano, Gregorio Mariotti, 1735.

Il trionfo della vocazione religiosa contro le lusinghe del mondo. Componimento per musica da cantarsi nella chiesa delle RR. Madri di S. Gio. Batista de' Cavalieri in Via S. Gallo in occasione dell'ingresso in Monastero dellillustriss. signora Anna Maria Vasoli Piccinini, Firenze, Pietro Gaetano Viviani, 1740.

Debbora componimento sacro per musica da cantarsi in occasione, che prende l'abito religioso nell'insigne monistero di S. Chiara in Cesena [...] Anna Maria Masini [...], Roma, Antonio de’ Rossi, 1742.

Il trionfo della casta Susanna. Componimento sacro a quattro voci e più stromenti da cantarsi nel venerabile e real Monistero del SS. Salvatore in occasione di prender l'abito monacale la sig. suor Maria Casimira detta nel secolo D. Catarina Drago e Naselli. Sotto il felice governo della reverenda madre suor Giuseppa Melchiora Lanza seconda volta abadessa. Musica del sig. Gio. Gualberto Brunetti, Palermo, Angelo Felicella, 1742.

La sposa de' sacri cantici. Componimento drammatico da cantarsi per lo solenne ingresso nel venerabil Monastero della SS.ma Concezione detto il Monastero Nuovo in via della Scala dellillustrissima signora Margherita Ginori
Italian 17th-and 18th-Century Dramatic Works with Music, Written for the Clothing and Profession Ceremonies, with Special Reference to Compositions Based on the Book of Judith

con nome di donna Caterina Teresa Maria Margherita, Firenze, Bernardo Paperini, 1742.

Il Tobia. Oratorio in musica da cantarsi nella occasione che veste l'abito religioso benedettino nel nobilissimo monastero dello Spirito Santo di Cesena sua patria la nobil donzella [...] marchesa Ippolita Locatelli Orsini. Dedicato [...] all'eminentiss. [...] cardinale Giacomo Oddi legato di Romagna dal marchese Fabio Locatelli Orsini padre della detta monacanda, Forlì, Achille Marozzi, 1750.

Lo sposalizio d'Ester con Assuero. Componimento sacro da cantarsi nel venerabile, e real Monistero di N. Signora dell'Assunta in occasione di vestir l'abito religioso la signora D.a Leonora Spadafora, e Moncada dé principi di Maletto, e Venetico, nobili Veneti orc. col nome di Suor Maria Catarina del Cuor di Gesù sotto il governo della rev. madre Suor Emmanuela Leonora di Gesù Maria, quarta volta priora, Palermo, appresso Angelo Felicella, 1752.

Il sacrifizio di Gefte. Dialogo a quattro voci, e piu stromenti da cantarsi nella venerabile Chiesa del Monastero di S. Maria di Monte Vergine per lo monacato della signora. D.a M.a Gioachima Marassi, e Naselli: sotto il felice governo della rev. madre abadessa Soro Rosa Maria Perlongo, Palermo, nella stamperia di Angelo Felicella, 1753.

Rut nel campo di Booz. Azione sacra da cantarsi nel regal Monistero di Reginaceli in occasione della monacazione dell'eccellentissima signora D. Giulia Riario Ruspigliosi de' duchy Riario, marchesi di Corleto ec., Napoli, Stamperia Muziana, 1759.

Lo sposalizio di Rebecca. Componimento sacro per musica da cantarsi in occasione che veste l'abito religioso nel real Monastero di Reginaceli di Napoli l'eccellentissima [...] D. Francesca Maria Caracciolo de' principi d'Avellino. Dedicato a sua eccellenza [...] D. Maria Antonia Caraffa principessa d'Avellino ec.ec. amantissima genitrice della medesima, Napoli, Giuseppe Severini Boezio, 1760.

La morte d'Abel componimento drammatico del signor abate Pietro Metastasio romano. Da cantarsi nel monastero di S. Chiara di Lecce, per la monacazione dell'eccell. signora d. Eleonora Chjurlia de' marchesi di Lizzano, e contidella Rocca forzata, Napoli, nella stamperia Abbaziana, 1761.

Lo sposalizio di Abigaelle con Davide. Componimento sacro per musica da cantarsi in occasione che veste l'abito religioso nel real Monastero di Reginaceli di Napoli la eccellentissima signora D. Argentina Mollo de' duchi di Lusciano, Napoli, Stamperia Manfrediana, 1767. 


\section{S sciendo}

Lo sposalizio di Mosè e di Sefora. Cantata in musica a tre voci in occasione, che fa la solenne professione nel venerabile monistero di S. Andrea di Ascoli la nobil religiosa Angela Teresa Novelli patrizia ascolana, Ascoli, Valenti, 1774.

La gara tra la fede, e la fortezza. Cantata a tre voci In occasione che veste l'Abito Religioso l'Eccellentissima Signora D. Maria Luisa De’ Principii Pignatelli Nel Real Monistero di Regina Coli di Napoli 1776 (manuscript copy in Biblioteca privata Giuseppe Pastore in Lecce, MS.A.18).

Invito alle spirituali nozze con Gesù Cristo. Dramma sacro composto dal molto illustre e reverendo signore D. Giambattista Paderni Accademico Industrioso ed Infiammato ed umilmente offerto in attestato di parentela da Antonio Maria Minelli alla molto reverenda madre suor Nicola Guzmana Maria Antonia al secolo [...] Catterina Lucia Rossi cittadina Bolognese professante i voti solenni di religione nel nobilissimo [...] monistero di S. Pietro Martire, Bologna, Stamperia del Sassi, 1779.
Italian 17th-and 18th-Century Dramatic Works with Music, Written for the Clothing and Profession Ceremonies, with Special Reference to Compositions Based on the Book of Judith

Anna Ryszka-Komarnicka is an Assistant Professor at the Institute of Musicology, the University of Warsaw. She completed her PhD dissertation The Oratorios by Pasquale Anfossi (1727-97) thanks to a grant from the Polish Committee for Scientific Research and a scholarship from the Lanckoronski Foundation. Her studies concentrate on the cultural history of music, especially Polish and Italian, in the $17^{\text {th }}, 18^{\text {th }}$ and $19^{\text {th }}$ centuries. In 2011-2013 she received a grant from the National Science Centre in Kraków for a research project on the Book of Judith in Italian Oratorios of the Baroque Era (1621-c.1750). She published a monograph under the same title in 2017 , thereby obtaining her postdoctoral degree in 2019. Since 2018 she has been a member of the German research group in the Polish-German project PASTICCIO. Ways of Arranging Attractive Operas, financed by the Polish and German research councils (NCN and DFG). 